\title{
Pathways from trade to health
}

\author{
Teresa Cyrus ${ }^{1}$
}

$\begin{array}{lll}\text { Suggested citation } & \begin{array}{l}\text { Cyrus T. Pathways from trade to health. Rev Panam Salud Publica. 2018;42:e51. } \\ \text { https://doi.org/10.26633/RPSP.2018.51 }\end{array}\end{array}$

ABSTRACT International trade has increased over time, both in volume and as a share of gross domestic product, and international trade agreements have proliferated. This rise in trade has many potential impacts on health outcomes. Trade raises living standards, allowing for greater spending on education and medical care, which improves health. However, trade may worsen intranational inequality, leading to increased stress and adverse impacts on mortality. Labor markets are affected by international trade, and the resulting changes in unemployment, working hours, and injury rates have an impact on health outcomes. Trade may induce adverse environmental impacts, such as increased pollution, leading to worsened health. Reductions in prices as a result of changes to trade policy may increase the consumption of unhealthy goods, including tobacco and processed foods, thus worsening the prevalence of noncommunicable diseases. Trade agreements may affect the ability of governments to legislate health-improving policies. Overall, international trade and trade agreements may have both positive and negative effects on health outcomes; government policy may be used to ameliorate any adverse effects of trade.

Keywords Internationality; global health; economics.

Between 1960 and 2015, the worldwide average share of trade in gross domestic product (GDP) rose from $24 \%$ to $58 \%$ (1), and the volume of merchandise export flows grew from US\$ 130 billion to US\$ 16 trillion (2). As well, as of June 2017 , the number of regional trade agreements in force stood at 296 (3), and every member of the World Trade Organization (WTO) was a signatory to at least one trade agreement. Rising GDP over the same time period has allowed greater resources to be devoted to curbing communicable diseases, but has also led to an increase in unhealthy behaviors that

Dalhousie University, Halifax, Nova Scotia, Canada. Send correspondence to Teresa Cyrus at tcyrus@dal.ca have driven noncommunicable diseases (NCDs) - including cardiovascular diseases, cancer, chronic respiratory diseases, and diabetes-to the forefront of health agencies' awareness and efforts. According to the World Health Organization, noncommunicable diseases are now responsible for $70 \%$ of all deaths globally (4).

To what extent are trade and trade agreements responsible for NCDs? Does international trade have a positive or an adverse effect on health outcomes? Studies that have examined the direct impact of trade on health have used regression analysis without specifying the causal pathway. Levine and Rothman (5), Owen and $\mathrm{Wu}$ (6), and Stevens et al. (7) use cross-country data and find that trade leads to improved measures of health, from infant mortality to life expectancy, at least for developing countries. Herzer (8) uses panel data methods to show a link between the trade share in GDP and life expectancy, and finds that trade is responsible for $12 \%$ of the annual rise in life expectancy in his sample of 74 countries; he finds a larger effect in lower-income countries.

However, rather than trying to establish a statistical link between trade and health, a more useful way to examine this relationship is to explore the precise causal pathways by which these two variables are connected. This paper describes six main pathways, listed in Table 1, by which international trade flows and international trade policy have 
TABLE 1. Pathways from trade to health, and their potential mechanisms

\begin{tabular}{|c|c|}
\hline Pathway & Potential mechanism \\
\hline $\begin{array}{l}\text { 1. Trade affects health by raising living } \\
\text { standards }\end{array}$ & $\begin{array}{l}\text { Increased trade } \rightarrow \text { growth in gross domestic product per capita } \\
\rightarrow \text { reduction in material deprivation } \rightarrow \text { reduced mortality and } \\
\text { increased life expectancy }\end{array}$ \\
\hline 2. Trade affects health by changing inequality & $\begin{array}{l}\text { Increased trade } \rightarrow \text { rise in income inequality } \rightarrow \text { increased stress } \\
\text { and reduced social cohesion } \rightarrow \text { increased mortality and reduced } \\
\text { life expectancy }\end{array}$ \\
\hline $\begin{array}{l}\text { 3. Trade affects health through changing the } \\
\text { labor market }\end{array}$ & $\begin{array}{l}\text { Increased trade } \rightarrow \text { increased unemployment and reduced } \\
\text { earnings } \rightarrow \text { worsened physical and mental health, higher injury } \\
\text { rates }\end{array}$ \\
\hline $\begin{array}{l}\text { 4. Trade affects health through changing the } \\
\text { environment }\end{array}$ & Increased trade $\rightarrow$ increased pollution $\rightarrow$ increased mortality \\
\hline $\begin{array}{l}\text { 5. Trade policy changes markets for particular } \\
\text { goods }\end{array}$ & $\begin{array}{l}\text { Tariff reductions } \rightarrow \text { increased consumption of health-reducing } \\
\text { goods } \rightarrow \text { worsened health outcomes }\end{array}$ \\
\hline 6. Trade policy influences the regulatory space & $\begin{array}{l}\text { Trade agreements } \rightarrow \text { longer patent protection } \rightarrow \text { increased } \\
\text { pharmaceutical prices } \rightarrow \text { worsened health outcomes }\end{array}$ \\
\hline
\end{tabular}

Source: Prepared by the author based on the study results.

been shown to impact health: 1) through changing living standards; 2 ) through increased inequality; 3) through impacts on the labor market; 4) through affecting the environment; 5) through changing markets for particular goods; and 6) through influencing the regulatory space.

\section{TRADE AFFECTS HEALTH BY RAISING LIVING STANDARDS}

Trade affects health by boosting the GDP, which allows for higher living standards. Empirical studies in the early trade and growth literature found evidence that trade causes growth in per capita income, but these cross-country studies were critiqued for their potential endogeneity bias. More careful work addressed these empirical concerns. For example, using an instrumental variable based on geography, Frankel and Romer find that a one percentage point rise in the trade share increases income per person by $2 \%$ (9). Lee et al. (10) control for endogeneity using a simultaneous equations system and identification through heteroscedasticity, and they find a small positive effect of openness on growth. Many recent studies continue to find that trade causes growth. For example, Eicher and Kuenzel show that a one standard deviation rise in their measure of exports increases growth in developing countries by one percentage point (11). However, while trade has not been shown to reduce growth, it is common to find that trade has no impact on growth. Durlauf et al. (12) find no robust effect of openness on growth in a sample of 57 countries.
A subset of the trade and growth literature focuses on resource-rich countries, with a common finding of a resource "curse." Van der Ploeg shows that, if a country's exports are primary goods, growth tends to be low if accompanied by low-quality institutions, such as corruption and poor rule of law (13). Sala-iMartin and Subramanian argue that the way natural resources impair growth is typically through adversely affecting institutional quality (14).

The so-called "new new" trade theory, which uses firm-level data, provides convincing evidence that exposure to trade causes the least productive firms to exit, leading to welfare gains through a rise in aggregate productivity. Using data for the United States of America, Bernard et al. show that lower trade barriers cause aggregate productivity to rise (15). Pavcnik examines Chile's trade liberalization and finds that it led to increased aggregate productivity, at least partly due to productivity increases within plants (16).

Increased GDP allows for greater expenditures on the goods and services that improve health, most importantly education and medical care. In addition, a large body of literature shows that income and health outcomes are strongly linked. Pritchett and Summers examine the effect of GDP per capita on infant and child mortality and on life expectancy (17). To control for reverse causality, they use instrumental variables as their estimation technique, together with panel data covering 111 countries over a 25 -year period. They find a robust relationship between GDP per capita and health outcomes: a $10 \%$ rise in per capita income is associated with a $2 \%$ to $4 \%$ drop in infant mortality. Biggs et al. examine data from 1960 through 2007 for 22 Latin American countries and find that a $1 \%$ increase in GDP per capita is associated with 0.06 more years of life expectancy and a $1 \%$ reduction in infant mortality; the effects are even larger if inequality is held constant (18). Clark uses panel data for 163 countries during the 1980-2005 period and shows that increases in GDP per capita raise life expectancy and reduce infant mortality, especially at low levels of development (19).

For low- and middle-income countries, a rise in trade and a corresponding increase in average income reduces material deprivation and improves health by lowering mortality and raising life expectancy. Between 1960 and 2015, for this group of countries, the trade share in GDP rose from $20 \%$ to $50 \%$, while life expectancy at birth rose from 47 years to 70 years, and the infant mortality rate dropped from 154 to 35 per 1000 births (1). These health gains have likely occurred by reducing the prevalence of communicable diseases; however, as countries grow richer, such health improvements may slow or even reverse due to NCDs.

\section{TRADE AFFECTS HEALTH BY CHANGING INEQUALITY}

The second pathway from trade to health is through changing inequality. Even if trade improves average incomes in a country, trade is unlikely to raise income for all workers. Trade theory, in fact, suggests that an increase in trade has differential effects on workers. Standard trade theory predicts that trade will lower the real wages of unskilled workers in industrial countries and raise the real wages of unskilled workers in developing countries, leading to a rise in income inequality in higher-income countries and a fall in inequality in lower-income countries.

There is evidence of rising income inequality since the early 1980s in developed countries. Roser and Cuaresma examine 32 developed countries over a 40 -year period and show that, as predicted by trade theory, a one standard deviation rise in imports from developing countries leads to a $6 \%$ rise in the Gini index (20). 
Contrary to the prediction of trade theory, there is also evidence of rising inequality in developing countries. Using data for 65 developing countries between 1980 and 1999, Meschi and Vivarelli show that trade with high-income countries worsens income inequality, possibly due to technology diffusion that increases the returns to skill (21). Helpman et al. show that rising inequality worldwide and increased dispersion among workers, plants, and firms are consistent with the "new new" trade theory that focuses on firm heterogeneity. Heterogeneity in terms of firm productivity leads to heterogeneity in terms of export performance, as only the more productive firms are able to export, and evidence shows that successful exporters pay higher wages (22).

If trade worsens inequality, or lowers real wages for some workers, then there may be effects on health due to stress or reduced access to health services, although evidence is mixed. Babones examines 134 countries over the 1970-1995 period and finds a strong correlation between changes in inequality, as measured by the Gini coefficient, and changes in population health, as measured by infant mortality and life expectancy: a rise in inequality of one Gini point is associated with a decline of 0.4 to 0.5 years in life expectancy (23). Cornia et al. show that inequality may impact mortality through a worsening of material deprivation, psychosocial stress, and social cohesion (24). Some studies, such as ones by DiezRoux et al. (25) and Kim et al. (26), suggest that inequality is linked to increased mortality from cardiovascular diseases. Kondo et al. examine 19 cross-sectional studies and conclude that inequality may modestly decrease self-reported health status due to stress and the erosion of social cohesion (27). Pickett and Wilkinson, in a meta-analysis, find strong evidence that inequality is linked to worsened population health and well-being, possibly due to chronic stress (28).

However, many studies find no causal link from inequality to health. In an early survey, Deaton finds no evidence of a cross-country relationship between inequality and health outcomes (29). Herzer and Nunnenkamp find that income inequality has a negative effect on health in developing countries but, surprisingly, a positive effect in developed countries; they posit that inequality is associated with higher-quality health care systems that have spillover effects (30). Using tax data for 12 developed countries between 1903 and 2003, Leigh and Jencks find that the income share of the top decile is positively related to infant mortality and negatively related to life expectancy, but the relationship becomes insignificant once country and year fixed effects are included (31).

\section{TRADE AFFECTS HEALTH THROUGH CHANGING THE LABOR MARKET}

International trade affects workers in the labor market, with many possible implications for mental or physical health. A highly influential paper by Autor et al. uses data at the local labor market level in the United States to measure exposure to Chinese imports and finds that increased Chinese imports into the United States since 1990 have resulted in increased unemployment, reduced labor force participation, and reduced earnings (32). McManus and Schaur (33) and Lang et al. (34) use the Autor et al. technique to determine how import exposure affects worker health in local labor markets. McManus and Schaur find that workplace injuries and illness rates rise in United States manufacturing firms that compete with imports (33). Lang et al. find that increased imports from China worsen the mental and physical health of workers in the United States, not only directly but also indirectly, through interpersonal spillovers or through being displaced into unemployment (34). Colantone et al. analyze panel data from the United Kingdom and show that greater import competition leads to worsened mental health due to higher unemployment, lower wage growth, and a resulting increase in stress (35).

Pierce and Schott examine an exogenous shock to United States trade policy and find that United States counties that were more exposed to international competition from China had higher mortality rates, especially due to suicide (36). Their interpretation is that this was due to disruption in the labor market that caused higher unemployment and lower income. The increased mortality rates they uncover were concentrated among white males, and the counties that were more exposed to trade experienced larger declines in manufacturing employment, which had a greater impact on white males than on others. Hummels et al. use data from Denmark to show that higher exports lead to longer working hours, higher on-the-job injury rates, and increased hospitalizations for heart attack and stroke (37).

\section{TRADE AFFECTS HEALTH THROUGH CHANGING THE ENVIRONMENT}

The fourth way that trade may impact health is by affecting environmental outcomes, such as air and water pollution. The negative impact of pollution on individual health and well-being is well established in the health sciences literature. Economists have contributed to this understanding by using quasi-experimental techniques to control for nonrandom assignment as well as avoidance behavior. For example, utilizing data for the United States, Chay and Greenstone use the fall in manufacturing output during the 1980s recession to determine how total suspended particulates affect infant mortality (38). Currie et al. use the mother's physical address to assign pollution levels, employing maternal fixed effects models to translate declining carbon monoxide to higher birth weight and reduced infant mortality in the state of New Jersey (39). In the developing country context, Ebenstein uses water pollution data from China to show the link from water quality to digestive cancers (40), and Arceo et al. quantify the relationship between more stringent air quality regulations in Mexico City and the subsequent decline in neonatal and infant mortality (41).

In contrast to the environment-health link, the pathway from trade to the environment is not as clear-cut. Trade's impact on pollution can be divided into three areas: 1) the scale effect, measured by economic activity, which tends to raise pollution; 2) the technique effect, measured by per capita domestic income, which raises the demand for environmental quality and therefore tends to reduce pollution; and 3) the composition effect, measured by the capital-labor ratio, which may raise or lower pollution, depending on a country's comparative advantage.

Antweiler et al. find that GDP and the capital-labor ratio raise sulfur dioxide emissions, so the scale and composition effects indicate that trade harms the environment (42). However, the technique 
effect works in the opposite direction. There is a negative relationship between per capita income and pollution, and this effect is strong enough to mean that, overall, freer trade is good for the environment. Frankel and Rose use cross-country data on three measures of air pollution to find a similar result, that trade openness reduces pollution (43). Copeland and Taylor survey the literature and conclude that there is evidence of an environmental Kuznets curve, with rising per capita incomes tending to improve environmental quality (44). They also assert that environmental regulations affect trade by influencing plant location, thus showing a pollution haven effect. The literature on the pollution haven effect is inconclusive, but research by Dam and Scholtens indicates that the quality of a country's institutions determines whether it will become a pollution haven: countries with poor institutions attract "dirty" companies (45).

While most researchers have not found a clear negative impact of trade on the environment, a recent study using Chinese data demonstrates the effects of trade on regional pollution levels. Bombardini and Li use air quality data from China to show that a rise in the pollution content of exports increases infant mortality from cardiorespiratory conditions (46).

In addition to affecting pollution, trade can influence natural resources, which could comprise trade in natural resources or trade in agricultural products made possible by resource conversion. Institutional quality is especially important. In a survey of the literature on trade and resources, Bulte and Barbier claim that trade openness may reduce welfare when institutions, such as property rights, are poor (47). For their part, Barbier et al. show that a rise in the agricultural export share raises agricultural land conversion when there is corruption in government (48).

\section{TRADE POLICY CHANGES MARKETS FOR PARTICULAR GOODS}

International trade agreements may affect the consumption of particular goods. Consumers respond to prices, and reductions in tariffs and quotas that lower prices therefore tend to increase consumption. If consumption of goods, including alcohol, tobacco, and processed foods, rises, then health is impacted through escalating heart disease, lung cancer, diabetes, and so on, as shown by Siegel et al. (49).

The World Health Organization states that, since 1980, there has been a doubling of obesity worldwide, and that, in $2014,39 \%$ of adults were overweight and $13 \%$ were obese (50). Blouin et al. present several case studies showing how trade liberalization, by reducing the prices of unhealthy foods, may have led to a rise in obesity and chronic diseases in many developing countries (51). Clark et al. describe how the North American Free Trade Agreement facilitated exports of corn, soybeans, sugar, snack foods, and meat products from the United States to Mexico between 1994 and 2008; over the same period, the prevalence of overweight and obesity in Mexico rose (52). Miljkovic et al. find a positive and significant effect of trade on obesity in a panel data set covering 79 countries, with a $10 \%$ rise in trade openness being associated with a $2.9 \%$ increase in the prevalence of obesity, and with a larger effect in developing countries than in developed countries (53). Costa-Font and Mas also show a robust association between globalization and obesity in a study on 26 countries (54). They find that the effect works not through lower prices, but through a change in diet and lifestyle: a one standard deviation rise in the social aspect of globalization (such as changes in information flows and personal contact) is associated with a $13.7 \%$ increase in obesity.

While the research has focused on increased consumption of health-reducing goods, it is also possible that we could see lower prices and increased consumption of health-improving goods, such as fresh foods, medical devices, mobility aids, and fitness equipment, although little research has been done to date on measuring these effects.

\section{TRADE POLICY INFLUENCES THE REGULATORY SPACE}

Lastly, trade policy may influence the ability of governments to enact and enforce legislation that affects health. Modern trade and investment agreements lead to concern over investor-state dispute settlement provisions and regulatory harmonization initiatives that may provide challenges to existing or proposed health and safety regulations.
McNeill et al. discuss the asymmetries in bargaining power between small and large countries in these negotiations, which may lead to large concessions being made by smaller, poorer nations in order to secure access to larger, richer countries' markets (55).

In particular, trade agreements may lessen the ability of governments to restrict advertising or to enforce laws on plain packaging or the addition of warning labels, although trade laws require simply nondiscriminatory treatment. On the other hand, Drope and Lencucha describe how the development of international norms allows for such norms to become encoded into law over time, as with the Framework Convention on Tobacco Control (56).

The Agreement on Trade-Related Aspects of Intellectual Property Rights (TRIPS) requires WTO member countries to maintain 20 years of patent protection, although the 1995 TRIPS agreement was amended by a 2003 waiver, made permanent in 2017, allowing for the import of generic versions of patented medicines through compulsory licensing. Patents on pharmaceutical products comprise a trade-off between the need to provide incentives to firms to undertake the costly research and development required to bring new drugs to the market and the resulting higher prices of pharmaceuticals. Smith et al. discuss how higher drug prices may have negative health implications for those who cannot afford to buy needed drugs, especially those living in developing countries (57). Duggan et al. examine India's 2005 reform of its patent system to comply with TRIPS (58). They exploit variation in the timing of patent decisions and find that prices have risen on average by $3 \%$ to $6 \%$ after a patent for a molecule is granted, but they find no significant change in the drug quantities sold or in the number of firms selling pharmaceuticals in India.

The purported benefit of TRIPS is the impetus to increase innovation. Kyle and McGahan (59) examine patent protection in 192 countries over the 1990-2006 period, making use of variation in the timing of patent laws. They find that patent protection is associated with increased research and development in pharmaceuticals in rich countries but not in poor nations. Kyle and Qian (60) examine how the patent protection required by TRIPS has affected pharmaceutical markets in 60 countries between 2000 and 2013 . 
They find that TRIPS has led to higher prices, higher quantities sold, and a faster launch of new pharmaceutical products. They also find that countervailing policies were successful in that the rise in price due to patents is smaller in poor countries.

\section{CONCLUSIONS}

Since the Second World War, international trade has risen both in absolute terms and as a share of GDP, but this increased reliance on trade has had both positive and negative effects on health. The literature suggests that trade has raised average incomes, which has allowed for improvements in life expectancy and mortality through reducing communicable diseases. At the same time, however, evidence suggests that trade has contributed to the growth in intranational inequality seen in both industrialized and developing countries. In addition, this rise in inequality is linked to a worsening of stress and a decrease in social cohesion, adversely affecting health and well-being. Recent evidence suggests that labor markets are impacted by both exports and imports, leading to worsening physical and mental health, as well as workplace injuries. While empirical studies clearly show that pollution adversely affects health, evidence is unclear as to whether trade worsens or improves the environment. By opening up markets and reducing prices, trade liberalization encourages the consumption of processed foods and other healthreducing goods. Finally, by forcing longer patent periods, trade agreements raise the prices of pharmaceuticals, which increases innovation but may worsen health outcomes in low-income countries. Overall, while globalization may have strong momentum, researchers and policymakers are recognizing the need for accompanying policy changes to protect the health of domestic residents.

There are many options for governments to support health outcomes with government policy. Policies to address the health effects of trade-induced income inequality or unemployment might

\section{REFERENCES}

1. World Bank. World Development Indicators. Available from: http://databank.worldbank.org $/$ data $/$ reports.aspx? source=world -development-indicators Accessed on 18 July 2017.

2. World Trade Organization. Statistics Database. Available from: http:/ / stat.wto. org Accessed on 18 July 2017.

3. World Trade Organization. Regional Trade Agreements Information System. Available from:http://rtais.wto.org/UI/PublicAllRTA List.aspx Accessed on 18 July 2017.

4. World Health Organization. Noncommunicable diseases fact sheet. 2017. Available from: http:/ /www.who.int/mediacentre/ factsheets/fs355/en/ Accessed on 18 July 2017.

5. Levine DI, Rothman D. Does trade affect child health? J Health Econ. 2005;25(3): 538-54.

6. Owen $\mathrm{AL}, \mathrm{Wu} \mathrm{S}$. Is trade good for your health? Rev Int Econ. 2007;15(4):660-82.

7. Stevens P, Urbach J, Wills G. Healthy trade: the relationship between open trade and health. Foreign Trade Rev. 2013; 48(1):125-35.

8. Herzer D. The long-run relationship between trade and population health: evidence from five decades. World Econ. 2017;40:462-87.

9. Frankel J, Romer D. Does trade cause growth? Am Econ Rev. 1999;89(3):379-99.

10. Lee HY, Ricci LA, Rigobon R. Once again, is openness good for growth? J Dev Econ. 2004;75:451-72.

11. Eicher TS, Kuenzel DJ. The elusive effects of trade on growth: export diversity and economic take-off. Can J Econ. 2016; 49(1):264-95.

12. Durlauf SN, Kourtellos A, Tan CM. Are any growth theories robust? Econ J. 2008; 118:329-46.

13. Van der Ploeg F. Natural resources: curse or blessing? J Econ Lit. 2011;49(2):366-420. the natural resource curse: an illustration from Nigeria. J Afr Econ. 2013;22(4): 570-615.

15. Bernard AB, Eaton J, Jensen JB, Kortum S. Plants and productivity in international trade. Am Econ Rev. 2003;93(4):1268-90.

16. Pavcnik N. Trade liberalization, exit, and productivity improvements: evidence from Chilean plants. Rev Econ Stud. 2002; 69:245-76.

17. Pritchett L, Summers L. Wealthier is healthier. J Hum Resour. 1996;31:841-68.

18. Biggs B, King L, Basu S, Stuckler D. Is wealthier always healthier? The impact of national income level, inequality, and poverty on public health in Latin America. Soc Sci Med. 2010;71:266-73.

19. Clark R. World health inequality: convergence, divergence, and development. Soc Sci Med. 2011;72:617-24.

20. Roser M, Cuaresma JC. Why is income inequality increasing in the developed world? Rev Income Wealth. 2016; 62(1):1-27.

21. Meschi E, Vivarelli M. Trade and income inequality in developing countries. World Dev. 2009;37(2):287-302.

22. Helpman E, Itskhoki O, Muendler MA, Redding, SJ. Trade and inequality: from
14. Sala-i-Martin X, Subramanian A. Addressing include government-funded health care, unemployment insurance, education spending, and worker training programs. If trade leads to increased workplace injuries, then the appropriate policy focus is on worker training and regulations to strengthen workplace safety legislation. Stricter regulations on air and water quality may ameliorate the effects of trade-induced pollution. If increased globalization is to blame for rising consumption of unhealthy products, then tax policy and consumer education can be utilized. Finally, governments must support their health agencies when trade policies and trade agreements are drafted, so that population health is brought to the forefront of negotiations as a primary concern.

\section{Conflicts of interest. None declared.}

Disclaimer. Authors hold sole responsibility for the views expressed in the manuscript, which may not necessarily reflect the opinion or policy of the RPSP/ PAJPH or PAHO. theory to estimation. Rev Econ Stud. 2017;84:357-405.

23. Babones SJ. Income inequality and population health: correlation and causality. Soc Sci Med. 2008;66:1614-26.

24. Cornia GA, Rosignoli S, Tiberti L. Globalisation and health: impact pathways and recent evidence. Available from: http: / / escholarship.org/uc/item / 2358z815 Accessed on 24 August 2016.

25. Diez-Roux AV, Link BG, Northridge ME. A multilevel analysis of income inequality and cardiovascular disease risk factors. Soc Sci Med. 2000;50:673-87.

26. Kim D, Kawachi I, Vander Hoorn S, Ezzati M. Is inequality at the heart of it? Crosscountry associations of income inequality with cardiovascular diseases and risk factors. Soc Sci Med. 2008;66:1719-32.

27. Kondo N, Sembajwe G, Kawachi I, van Dam RM, Subramanian SV, Yamagata Z. Income inequality, mortality, and selfrated health: meta-analysis of multilevel studies. BMJ. 2009;339:1178-81.

28. Pickett KE, Wilkinson RG. Income inequality and health: a causal review. Soc Sci Med. 2015;128:316-26.

29. Deaton A. Health, inequality, and economic development. J Econ Lit. 2003; 41(1):113-58.

30. Herzer D, Nunnenkamp P. Income inequality and health: evidence from developed and developing countries. Econ. 2015;9:1-57.

31. Leigh A, Jencks C. Inequality and mortality: long-run evidence from a panel of countries. J Health Econ. 2007;26:1-24. 
32. Autor DH, Dorn D, Hanson GH. The China syndrome: local labor market effects of import competition in the United States. Am Econ Rev. 2013;103(6): 2121-68.

33. McManus TC, Schaur G. The effects of import competition on worker health. J Int Econ. 2016;102:160-72.

34. Lang M, McManus TC, Schaur G. The effects of import competition on health in the local economy. Available from: https: / / ssrn. com / abstract $=2668394$ Accessed on 15 August 2016.

35. Colantone I, Crino R, Ogliari L. The hidden cost of globalization: import competition and mental distress. (CEPR Discussion Paper No. DP10874). London: Centre for Economic Policy Research; 2015.

36. Pierce JR, Schott PK. Trade liberalization and mortality: evidence from U.S. counties. (NBER Work Pap Ser No. 22849). Cambridge, Massachusetts: National Bureau of Economic Research; 2016.

37. Hummels D, Munch J, Xiang C. No pain, no gain: the effects of exports on effort, injury, and illness. (NBER Work Pap Ser No. 22365). Cambridge, Massachusetts: National Bureau of Economic Research; 2016.

38. Chay KY, Greenstone M. The impact of air pollution on infant mortality: evidence from geographic variation in pollution shocks induced by a recession. Q J Econ. 2003;118(3):1121-67.

39. Currie J, Neidell M, Schmieder JF. Air pollution and infant health: lessons from New Jersey. J Health Econ. 2009;28(3):688-703.

40. Ebenstein A. The consequences of industrialization: evidence from water pollution and digestive cancers in China. Rev Econ Stat. 2012;94(1):186-201.

41. Arceo E, Hanna R, Oliva P. Does the effect of pollution on infant mortality differ between developing and developed countries? Evidence from Mexico City. Econ J. 2015;126:257-80.

42. Antweiler W, Copeland BR, Taylor MS. Is free trade good for the environment? Am Econ Rev. 2001;91:877-908.

43. Frankel JA, Rose AK. Is trade good or bad for the environment? Sorting out the causality. Rev Econ Stat. 2005;87(1):85-91.

44. Copeland BR, Taylor MS. Trade, growth, and the environment. J Econ Lit. 2004;42:7-71.

45. Dam L, Scholtens B. The curse of the haven: the impact of multinational enterprise on environmental regulation. Ecol Econ. 2012;78:148-56.

46. Bombardini M, Li B. Trade, pollution and mortality in China. (NBER Work Pap Ser No. 22804). Cambridge, Massachusetts: National Bureau of Economic Research; 2016.

47. Bulte EH, Barbier EB. Trade and renewable resources in a second best world: an overview. Environ Resour Econ. 2005; 30:423-63.

48. Barbier EB, Damania R, Leonard D. Corruption, trade and resource conversion. J Environ Econ Manage. 2005; 50:276-99.

49. Siegel KR, Bullard KM, Imperatore G, Kahn HS, Stein AD, Ali MK, et al. Association of higher consumption of foods derived from subsidized commodities with adverse cardiometabolic risk among U.S. adults. JAMA Intern Med. 2016;176(8):1124-32.

50. World Health Organization. Obesity and overweight fact sheet. Available from: www.who.int/mediacentre/factsheets/ fs311/en/ Accessed on 18 July 2017.

51. Blouin C, Chopra M, van der Hoeven R. Trade and social determinants of health. Lancet. 2009;373:502-7.

52. Clark SE, Hawkes C, Murphy SME, Hansen-Kuhn KA, Wallinga D. Exporting obesity: US farm and trade policy and the transformation of the Mexican consumer food environment. Int J Occup Environ Health. 2012;18(1):53-65.

53. Miljkovic D, Shaik S, Miranda S, Barabanov N, Liogier A. Globalisation and obesity. World Econ. 2015;38(8):1278-94.

54. Costa-Font J, Mas N. 'Globesity'? The effects of globalization on obesity and caloric intake. Food Policy. 2015;64:121-32.

55. McNeill D, Barlow P, Birkbeck CD, Fukuda-Parr S, Grover A, Schrecker T, et al. Trade and investment agreements: implications for health protection. J World Trade. 2017;51:159-82.

56. Drope J, Lencucha R. Evolving norms at the intersection of health and trade. J Health Polit Policy Law. 2014;39(3):591-631.

57. Smith RD, Correa C, Oh C. Trade, TRIPs, and pharmaceuticals. Lancet. 2009;373: 684-91.

58. Duggan M, Garthwaite C, Goyal A. The market impacts of pharmaceutical product patents in developing countries: evidence from India. Am Econ Rev. 2016;106(1):99-135.

59. Kyle MK, McGahan AM. Investments in pharmaceuticals before and after TRIPS. Rev Econ Stat. 2012;94(4):1157-72.

60. Kyle M, Qian Y. Intellectual property rights and access to innovation: evidence from TRIPS. (NBER Work Pap Ser No. 20799). Cambridge, Massachusetts: National Bureau of Economic Research; 2014.

Manuscript received on 4 October 2017. Revised version accepted for publication on 5 January 2018. 
RESUMEN

\section{Las vías del comercio a la salud}

Palabras clave
El comercio internacional ha aumentado con el transcurso del tiempo, tanto en volumen como en proporción del producto interno bruto, y han proliferado los acuerdos comerciales internacionales. Este incremento del comercio tiene muchas posibles repercusiones sobre los resultados en materia de salud. El comercio eleva los niveles de vida y permite un mayor gasto en educación y atención médica, lo cual mejora la salud. Sin embargo, el comercio puede empeorar la desigualdad intranacional, lo que genera mayor estrés y repercusiones adversas sobre la mortalidad. Los mercados laborales se ven afectados por el comercio internacional, y los cambios resultantes en materia de desempleo, jornadas de trabajo y tasas de traumatismos repercuten sobre los resultados en materia de salud. El comercio puede inducir efectos ambientales adversos, como mayor contaminación, lo que deteriora la salud. La reducción de los precios a consecuencia de los cambios en las políticas comerciales puede aumentar el consumo de productos poco saludables, como el tabaco y los alimentos procesados, lo que empeora la prevalencia de las enfermedades no transmisibles. Los acuerdos comerciales pueden afectar la capacidad de los gobiernos de legislar políticas que mejoren la salud. En términos generales, el comercio internacional y los acuerdos comerciales pueden tener tanto efectos positivos como negativos sobre los resultados en materia de salud, y se puede recurrir a las políticas gubernamentales para mitigar los efectos adversos del comercio.

Internacionalidad; salud global; economía.
RESUMO

\section{Trilhas do comércio à saúde}

Palavras-chave
O comércio internacional se expandiu tanto em volume como em proporção do produto interno bruto, multiplicando os acordos comerciais internacionais. Este crescimento pode ter grande impacto na situação da saúde. O comércio eleva o padrão de vida e permite gastos maiores com educação e assistência médica, o que melhora o estado de saúde das pessoas. Porém, pode agravar as desigualdades dentro de um mesmo país, causando aumento no estresse e resultados adversos na mortalidade. $\mathrm{O}$ comércio internacional surte efeito nos mercados de trabalho produzindo mudanças na taxa de desemprego, jornadas de trabalho e índices de acidentes que repercutem na saúde. O comércio pode ter um impacto negativo no ambiente, como o aumento da poluição, com prejuízo à saúde das pessoas. A queda nos preços resultante de mudanças na política comercial pode aumentar o consumo de produtos prejudiciais à saúde, como cigarros e alimentos processados, elevando a prevalência de doenças não transmissíveis. Os acordos comerciais podem interferir com a capacidade dos governos de estabelecer políticas para proteger a saúde. O comércio internacional e os acordos comerciais podem ter repercussão positiva ou negativa na saúde e os governos precisam dispor de políticas para atenuar os resultados desfavoráveis. 